This is the author's final, peer-reviewed manuscript as accepted for publication. The publisher-formatted version may be available through the publisher's web site or your institution's library.

\title{
Islamophobia and threat perceptions: explaining anti Muslim sentiment in the West
}

Sabri Ciftci

\section{How to cite this manuscript}

If you make reference to this version of the manuscript, use the following information:

Ciftci, S. (2012). Islamophobia and threat perceptions: Explaining anti Muslim sentiment in the West. Retrieved from http://krex.ksu.edu

\section{Published Version Information}

Citation: Ciftci, S. (2012). Islamophobia and threat perceptions: Explaining anti-Muslim sentiment in the West. Journal of Muslim Minority Affairs, 32(3), 293-309.

Digital Object Identifier (DOI): doi:10.1080/13602004.2012.727291

\section{Publisher's Link:}

http://www.tandfonline.com/doi/full/10.1080/13602004.2012.727291\#.UnQWsHDktLA 


\title{
Scheduled for 32.3
}

\section{Islamophobia and Threat Perceptions: Explaining Anti Muslim Sentiment in the West}

\section{SABRI CIFTCI}

\begin{abstract}
This paper investigates the determinants of anti Muslim sentiment in the West. Starting from the premise that Islamophobic attitudes are more nuanced than a simple dislike of Muslims, I focus on specific forms of attitudes which link Muslims to violence and terrorism. Data from the Pew Global Attitudes Surveys is used to test three theories: perceived threat, social identity, and cognitive capabilities. A series of logit estimations are used for the empirical analysis of individual level data in the United States, Great Britain, France, Germany and Spain. The results show that perceived realistic and symbolic threat is the most significant source of Islamophobic attitudes in the West. While individuals cognitively differentiate between general feelings toward Muslims and their specific characteristics, higher levels of education significantly reduces negative sentiments. A good number of Westerners think of Muslims as violent individuals while some believe that they support al Qaeda. Citizens in the West are more likely to associate Muslims with terrorism if they feel threatened by their physical and cultural existence.
\end{abstract}

\section{Introduction}

Anti Muslim sentiment has been on the rise in Western Europe and the United States. Recently, the degree of Islamophobia has been revealed on multiple occasions. To name just a few, debates about the construction of an Islamic center near Ground Zero and mosque controversies in a dozen states in the United States; anti veiling legislation in France; the 'minaret' row in Switzerland; and the killing of Turkish immigrants in Germany are some well known examples. Reports prepared by the European Center for Monitoring of Racism and Xenophobia (EUMC) ${ }^{1}$ in Europe and by Council on American-Islamic Relations (CAIR) ${ }^{2}$ in the United States also pointed to the rise of Islamophobia. Furthermore, recent polls found that Western citizens have strong negative feelings about Islam and Muslims. ${ }^{3}$

The main goal of this paper is to explain the sources of rising anti Muslim sentiments in the West. Although there is no agreement over the meaning of Islamophobia, this term is coined to capture the multiple forms of anti Muslim feelings, behavior, or policies. In this study, I examine the various attitudinal dimensions of this concept and especially focus on individual attitudes viewing Muslims as violent individuals who are supportive of terrorism. While Islamic 
violence and extremism stands at the crux of the debates about Islam, previous scholarly research, by and large, investigated the general feelings about Muslims. ${ }^{4}$ For a complete picture, we need to move away from this wholesale generalization of negative feelings and take a more nuanced approach differentiating the specific attitudinal dimensions of anti Muslim sentiment. To provide an example, the much debated cartoons in Denmark have depicted Prophet Mohammed and, in his person, Muslims as violent fanatics. This media depiction implies that Muslims are prone to violence and this may have an attitudinal counterpart in the individual cognition. Thus, it is imperative to separate the general views about Muslims from more specific attitudes linking Muslims to violence and terrorism and examine the micro level determinants of Islamophobic attitudes with this approach.

In this study, I utilize three theories developed by the students of ethnic/religious tolerance and racism: perceived realistic and symbolic threat, social identity, and cognitive capabilities. All three theories utilize the in-group versus out-group dynamic in different ways. After explaining the cross-linkages between in-group/out-group rationale and implications of these theories, I derive testable hypotheses. Pew Global Attitudes Survey (2006) is used for empirical testing. The survey included some major Western and Islamic countries as well as China, Japan, and Russia. Since the focus of this paper is anti Muslim sentiment in the West, I include non-Muslim respondents from the United States, Great Britain, France, Germany, and Spain.

The paper is organized as follows: First, a conceptual discussion of Islamophobia highlighting its attitudinal aspects is provided. Next, I introduce a theoretical framework and develop some hypotheses. Then I describe the data and the model followed by the results and a discussion. The results from a series of logit estimations show that Islamophobic attitudes have multiple dimensions and individuals differentiate between general feelings toward Muslims and attitudes about their specific characteristics. It is found that a good number of Westerners think of Muslims as violent and fanatical individuals while some believe that they support al Qaeda. Furthermore, the results reveal that perceived symbolic and realistic threat is the most significant source of Islamophobic attitudes while education significantly reduces anti Muslim sentiment.

\section{What Is Islamophobia?}

No agreement exists on the meaning of Islamophobia among scholars and policymakers. Lopez ${ }^{5}$ traces the origins of this concept to late nineteenth century and shows that the term had been redefined in the early twentieth century. Cesari ${ }^{6}$ argues that this term is "contested because it is often imprecisely applied to very diverse phenomena, ranging from xenophobia to anti terrorism”. According to Schiffer and Wagner, Islamophobia is a new form of racism where discrimination targets a religious community. In fact, they prefer to describe this phenomenon as "cultural racism". Taking a philosophical approach, Kalin ${ }^{8}$ argues that Islamophobia is a product of Western Liberal mindset confined to a narrow understanding of secularization that cannot 
accommodate another religion like Islam. As such, he argues that anti Muslim sentiments are related to the limits of pluralism and multiculturalism in the West.

The term is also defined as a hostile attitude or behavior toward Muslims. ${ }^{9}$ This distinction between attitudinal and behavioral dimensions is important and can be seen in the definition of this concept by prominent institutions on both sides of the Atlantic. The surveys conducted by the Pew Research Center in 2006 employed an attitudinal approach and included a question tapping the respondents' general feelings about Muslims. This item asked the respondents whether they had a very favorable, somewhat favorable, somewhat unfavorable, or very unfavorable opinion of Muslims. Similarly, Zimmerman defines Islamophobia as a sentiment of "unreasonable fear of Islam and Muslims". ${ }^{10}$ The reports prepared by EUMC, on the other hand, utilize a behavioral approach and include discriminatory practices and violence toward Muslims as indicators of Islamophobia throughout Europe.

While the concerns about Islamophobia have increased in the aftermath of $9 / 11$, it is hardly a product of this event as an attitude and behavior. The rise of anti Muslim sentiment goes back to 1980s, but the term was officially recognized in January 2001 by the Stockholm International Forum on Combating Intolerance. ${ }^{11}$ In the same year, the United Nations has condemned the rising anti Muslim prejudice and hatred of Islam by declaring it as much unwanted as anti Semitism. $^{12}$ In 1997, in its much cited report, Islamophobia: A Challenge for us All, the Runnymede Trust has described Islamophobia as "unfounded hostility towards Islam. It refers also to the practical consequences of such hostility in unfair discrimination against Muslim individuals and communities, and to the exclusion of Muslims from mainstream political and social affairs". ${ }^{13}$ According to the same report, Islamophobia has four interrelated dimensions which affect the values and practices against Muslims. These dimensions are exclusion, discrimination, prejudice, and violence. ${ }^{14}$ By and large, the Runnymede report has provided the most comprehensive definition of Islamophobia by developing eight components related to this concept. These components are as follows: ${ }^{15}$

- Islam is seen as a monolithic bloc, static and unresponsive to change.

- Islam is seen as separate and 'other'.

- Islam is seen as inferior to the West and is seen as barbaric, irrational, primitive and sexist.

- Islam is seen as violent, aggressive, threatening, and supportive of terrorism

- Islam is seen as a political ideology and is used for political or military advantage.

- Criticisms made of the West by Islam are rejected out of hand.

- Hostility towards Islam is used to justify discriminatory practices towards Muslims and exclusion of Muslims from mainstream society.

- Hostility to Muslims is seen as natural or normal.

The conceptual approach of Runnymede shows that Islamophobia can be thought as a latent construct with multiple dimensions. This definition includes such themes as otherness, inferiority, and fear of Islam and hence justifies the argument that Islamophobia is just a new form of religious prejudice ${ }^{16}$ or a new form of racism. In the Runnymede report, Islamophobia is also defined as perception of Islam as an aggressive and violent religion prone to terrorism. 
Western media has widely depicted Islam with these qualities to further strengthen the "phobia" side of this perception. Schiffer ${ }^{17}$ illustrates that media reports combine images of veiled women with the news about terrorism to construct a link between Muslims and violence. This is hardly a novel trend as, for long, some segments of Western news and entertainment media have portrayed Muslims as outsiders holding hostile intentions to Western civilization. ${ }^{18}$ In a similar vein, Sheikh, Price, and Oshagan ${ }^{19}$ found that most news about Muslims included such terms as terrorist, extremist, and radical.

By and large, portraying Muslims as violent and radical extremists is a visible tendency in select media outlets. ${ }^{20}$ At the same time, perceiving Muslims as carriers of these qualities may be prevalent in the realm of attitudes. Conceivably this is not the only or the most prevailing dimension of attitudes as they may range from a general negative feeling to the perception of Muslims as terrorists. Nonetheless, the terrorist bombings in the European capitals in the aftermath of $9 / 11$ and the media bias framing Islam as a violent religion makes this dimension of attitudinal Islamophobia important. Therefore, while this study aims to examine the attitudinal sources of anti Muslim sentiment, it gives more weight to the analysis of perceptions about Islamic violence and Muslim support for terrorism.

\section{The Attitudinal Determinants of Islamophobia}

The study of attitudes toward Muslims has proliferated within the last decade. ${ }^{21}$ These studies generally build on the scientific research about ethnic and religious intolerance, general ethnocentrism, and racism to explain the attitudinal sources of Islamophobia. Some prominent theories developed in this field include social identity theory, theories of perceived threat, and cognitive capabilities approach. All three theories employ a rationale based on perceptions of 'ingroup' and 'out-group.'

Social identity theory argues that social group membership forms the basis of a positive self-identity. ${ }^{22}$ People may carry different social identities including attachments to ethnic and religious groups or a nation. Social identity leads people compare their 'in-group' to the 'outgroup'. For example, people with strong national attachments will evaluate their 'in-group,' that is the members of a nation, more positively while perceiving the 'out-group' in a negative sense. Muslims are religious and most of the times ethnic outsiders to the Westerners. It is likely that they will be perceived as non native others or "a band of others". ${ }^{23}$ Some scholars found an association between religiosity and lack of tolerance in the United States. ${ }^{24}$ Thus, the in-group versus out-group dynamic is likely to generate negative attitudes about Muslims when religious and national identity is strong.

Hypothesis 1: Individuals with strong national identity are more likely to have negative attitudes toward Muslims.

Hypothesis 2: Individuals with strong religious identity are more likely to have negative attitudes toward Muslims. 
Theories of perceived threat can also be explained by the 'in-group' and 'out-group' rationale. According to this approach, a threat perception leads to negative feelings about 'outgroup' members in two forms: Realistic threat and symbolic threat. ${ }^{25}$ The former is an "existential" threat perception ${ }^{26}$ related to the "political and economic power or to the physical and material well-being of the 'in-group' or its members". ${ }^{27}$ In this vein, realistic conflict theory has been widely used to explain attitudes toward immigrants. ${ }^{28}$ According to this theory, when the resources are limited, competition over these resources may fuel discrimination, prejudice, and even conflict among groups competing for them. Since Muslims constitute a large proportion of immigrants in most Western countries, realist conflict theory and perceived realistic threat can be utilized to explain anti Muslim sentiment in the West. The argument here would be that Muslims compete for scarce economic resources like jobs, welfare benefits, and educational goods and hence will become targets of prejudice. It should be noted that this kind of threat goes beyond a perceived economic hazard to material benefits and it may contain any perception of danger towards one's interest ${ }^{29}$ including physical well-being. Accordingly, if Muslims are viewed as violent or supportive of terrorism, they may be perceived as a threat to the physical well-being in Western societies. 9/11 and the bombings in some major European capitals may have contributed to a threat perception related to the physical well-being of Westerners. For example, ${ }^{30}$ Cesari argues that a "Bin Laden Effect" has transformed Muslims into a public enemy in Western societies. The fact that the terrorist bombings in European capitals were carried by Muslim citizens born and raised in these countries may also have contributed to this kind of threat perceptions. ${ }^{31}$

The latter, symbolic threat is derived from racial attitudes research and symbolic racism theory. ${ }^{32}$ Rather than a perceived realistic threat, this approach argues that people are worried about symbols, national unity, or cultural values. ${ }^{33}$ Increasing the numbers of 'out-group' members may lead to an increased feeling of cultural threat directed towards the 'in-group' values. Consequently, a sense of conflict between the cultural values of 'in-group' and 'outgroup' may generate negative feelings toward the members of 'out-group'. Muslims are both immigrant workers and individuals with distinct cultural values. As immigrants, they compete for jobs and scarce resources in the labor market and as Muslims they represent values that are distinct from Western culture. Westerners may perceive Muslims as a source of danger or threat not only to their economic and physical well-being but also to their own values due to Muslim symbolic practices. ${ }^{34}$ Especially, the resistance of Muslims to integration in the European context may increase the degree of perceived symbolic threat and hence generate stronger negative attitudes. An example will be illustrative. Speaking in a church in Madison, Tennessee, the leader of the Dutch extreme right party Geert Wilders stated: ${ }^{35}$

We must stop the Islamization of our countries. And now, now Europe is looking slowly but gradually like Arabia...Islam is also coming to America, in fact Islam already is in America...We must repeat it over and over again, especially to our 
children, our Western values and culture based on Christianity and Judaism is better and superior to the Islamic culture.

Another example is the debate about building a mosque in ground zero and controversies about other mosque controversies throughout the US.. The impact of cultural threat argument can be more clearly observed in Europe where, compared to their counterparts in the US, Muslims are less educated, highly concentrated in ghettos, and cannot be integrated into the mainstream society. ${ }^{36}$ The popularity of concepts like Londonstan or Eurabia is a good example that would prove the significance of the predictions made by symbolic threat theory. By and large, and according to the argument provided above, Islamophobic attitudes may be caused by perceived realistic or symbolic threat.

Hypothesis3: Individuals who perceive Muslims as a threat to their well-being will have negative attitudes toward Muslims.

Hypothesis 4: Individuals who perceive Muslims' cultural practices as threatening to their own values will have negative attitudes toward Muslims.

Finally, cognitive capabilities approach implies that attitudes about different ethnic groups are more likely to be negative at low levels of education and knowledge. ${ }^{37}$ Selznick and Steinberg ${ }^{38}$ argue that prejudice depends on a cognitive simplification of the world and in the lack of knowledge and at low levels of education generalizations can be applied to all members of the 'out-group'. Education and knowledge may disprove prejudicial beliefs and increase the cognitive abilities to allow sophisticated analysis of the 'out-group' qualities. ${ }^{39}$ As such, it can be argued that higher education will decrease Islamophobic attitudes.

Hypothesis 5: Individuals with higher levels of education are less likely to have anti Muslim feelings

\section{Data and Model}

I utilize Pew Global Attitudes Survey conducted in the spring of 2006 in 15 countries for empirical analysis. Since the focus of this paper is attitudes toward Muslims in the West, I use data from non Muslim samples of five Western nations: United States, Britain, France, Germany, and Spain. These countries house Muslim populations with different characteristics. According to a report published by Pew Forum on Religion and Public Life ${ }^{40}$ Muslims were projected to constitute 7.5 percent in France, 5 percent in Germany, 2.3 percent in Spain, 4.6 percent in the United Kingdom and about 1 percent of the total population in the United States by 2010. Muslim immigrants in the United States are more educated, high skilled and sparsely dispersed around the country whereas European Muslims are generally less-educated, low skill individuals who are more densely concentrated in specific areas. ${ }^{41}$ It is known that North African Muslims 
are the largest group in Spain and France whereas majority of Muslims are Turk in Germany and of South Asian origin in the United Kingdom.

The surveys provide multiple items related to the different aspects of Islamophobic attitudes in these countries. Five questions were used to measure anti Muslim sentiments. The first item asks the respondents to evaluate a general feeling about Muslims and is worded as follows: "Please tell me if you have a very favorable, somewhat favorable, somewhat unfavorable, or very unfavorable opinion of Muslims?”

Very favorable (1)

Somewhat favorable (2)

Somewhat unfavorable (3)

Very unfavorable (4)

I recoded this item to create a dummy variable by combining favorable opinions under one category (a value of 0 ) and unfavorable opinions under another (a value of 1 ). Since the focus of this paper is the perceptions viewing Muslims as violent, fanatic, and supportive of terrorism, I picked items that are likely to measure these perceptions. One item taps the respondents' opinion about the consequences of Islamic identity and is worded as follows: "Which one of the following worries you most about Islamic identity in our country today?" One of the options is presented as "it can lead to violence." I used this item to create a dummy variable taking the value of 1 for those who reported that Islamic identity can lead to violence. This item provides a general view of Islamic religion and assess whether it is prone to violence. To measure more specific opinions, I used two items asking the respondents to choose among the qualities of Muslims. The surveys included a question asking about the qualities of Muslims. I chose two qualities which would allow me to capture the perceptions of Muslims as violent and fanatical individuals. The question asked:

Which of these characteristics do you associate with Muslims?

Muslims are violent

Muslims are fanatical

These two items were used to create two dichotomous variables and those who believe Muslims to be violent or fanatical are assigned a value of 1 and others 0 . Finally, I used an item asking the respondents to state whether they believe Muslims support al Qaeda or not. This item is used to assess if Westerners associate Muslims with terrorism.

In your opinion, how many Muslims in our country support Islamic extremists like al Qaeda, would you say most, many, just some or very few?

Very Few (1)

Just Some (2)

Many (3)

Most (4)

I created a dummy variable from the responses by assigning a value of 1 for those who believe that most or many Muslims support extremist groups like al Qaeda and by assigning a value of 0 otherwise. An initial look at the distribution of the responses to these questions is quite 
informative. I start with the responses to the question asking about general perceptions of Westerners about Muslims. Figure 1 shows the percentages of those who have favorable and unfavorable opinions of Muslims across five Western nations.

Figure 1: General Feelings about Muslims*

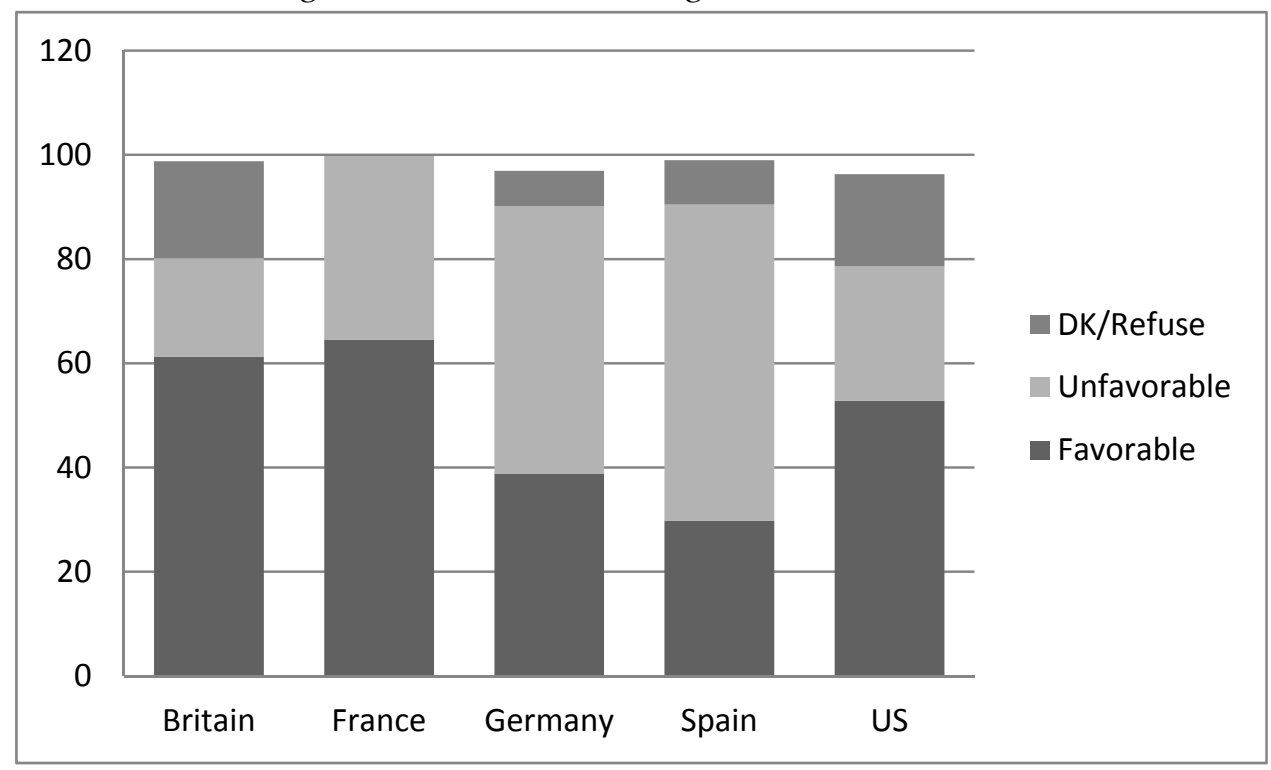

Source: Pew Global Attitudes Project. The great divide: How Westerners and Muslims view each other. Washington, DC: Pew Research Center; 2006.

*The bar heights represent percentages.

More than 60 percent of the respondents have favorable opinions about Muslims in Britain and France followed by the United States. In contrast, unfavorable opinion about Muslims appears to be the public opinion norm in Spain and Germany. The proportion of respondents with unfavorable opinion toward Muslims is 51 percent In Germany and 50 percent in Spain. Those who have not formed an opinion about Muslims constitute 19 percent of all respondents in Britain. The same figure is around 18 percent in the United States. This is an interesting result given the fact that the UK and the US were the targets of major terrorist attacks and they were at the forefront of the invasion of Iraq and Afghanistan. It looks like being target of a terrorist attack is not sufficient to assume a high level of anti Muslim sentiment in a given country as the favorability ratings for Muslims are high in Britain and France relative to those observed in Spain. The size of the Muslim population is not also uniformly correlated with negative feelings about Muslims. Adherents of Islam are rated favorably in France and Britain but unfavorably in Germany.

While I do not exclude sampling error as a possibility, wording of the question may also have produced such results. Since the question asks about a general feeling, it does not allow the respondents to differentiate between specific characteristics of Muslims that they like or dislike. The survey in hand includes some questions taping the respondents' attitudes about various 
characteristics of Muslims. Table 1 reports the percentage of individuals who responded with an affirmative statement to these items.

Table 1: Percentage of Muslims being perceived as Violent*

\begin{tabular}{lcccc}
\hline & $\begin{array}{l}\text { Islamic Identity } \\
\text { Leads to Violence }\end{array}$ & Muslims Violent & $\begin{array}{c}\text { Muslims } \\
\text { Fanatical }\end{array}$ & $\begin{array}{c}\text { Muslims Support } \\
\text { al Qaeda }\end{array}$ \\
\hline Britain & 12 & 29 & 43 & 27 \\
France & 27 & 40 & 50 & 28 \\
Germany & 23 & 45 & 70 & 22 \\
Spain & 19 & 60 & 83 & 68 \\
US & 19 & 47 & 46 & 54 \\
\hline
\end{tabular}

Source: Pew Global Attitudes Project. The great divide: How Westerners and Muslims view each other. Washington, DC: Pew Research Center; 2006.

*Cell entries represent percentages for affirmative responses.

The results reveal that a good proportion of Westerners associate Muslims with violence and terrorist groups. The responses to these four items vary across five countries. Spain and, to a certain extent, Germany appear to be outliers. For example, 60 percent of the respondents in Spain reported that they believe Muslims are violent. The same figure is 47 percent in the US, 45 percent in Germany, and 40 percent in France. In Britain this number has the lowest percentage at 29 percent. The Islamophobic attitudes are even higher for the item asking whether the respondents believe Muslims are fanatical or not. At the highest, 83 percent of the Spaniards believe that Muslims are fanatical followed by a 70 percent in Germany. Half of the French citizenry associate this quality with Muslims while the numbers are relatively low (but still high to lead to a significant intolerance) in the US (46 percent) and in Britain (43 percent). The responses to the question associating Muslims with terrorist organizations like al Qaeda stay at a lower percentage in three European countries (22, 27, and 28 percent respectively in Germany, Britain, and France). An alarming 68 percent of the Spaniards and 54 percent of Americans believe that Muslims in their country support terrorist organizations like al Qaeda. Finally, when asked about Islamic identity, a much lower percentage of respondents associate this identity with violence. These statistics show that relying on a single item asking about a general view of Muslims is not sufficient to explain Islamophobic attitudes. We need to assess individual attitudes about Muslims with more nuanced items. Overall, the above analysis demonstrates that individuals distinguish between different characteristics of Muslims when forming their attitudes.

While these descriptive figures are informative and provide insights about the aggregate public opinion, they do not explain why and to what degree citizens in these countries have anti Muslim feelings. I ran a series of logistic regressions to test the propositions derived from the relevant theories discussed above in order to explain the individual correlates of anti Muslim sentiment. I choose logistic regression because all of my dependent variables are dichotomous. 
The independent variables were coded from the items that capture the implications of three theoretical approaches discussed above.

Social identity theory argues that the need for self-identity is derived from a group membership and this kind of attachment will lead to a negative opinion about the members of the 'out-group'. Muslims are members of both ethnic and religious 'out-groups'. Accordingly, I use measures of national identity and religious identity to test the implications of this theory. These variables are created using the following question:

Do you think of yourself first as (name of country's people) or first as a (Muslim/Christian/Hindu)?

I coded a dummy variable with a value of 1 when respondents state that they think themselves as a country's people and 0 otherwise. Similarly, a dummy variable is created for those who report to think of themselves as Christian. I used four variables to test the perceived threat theory. The first variable is a dichotomous variable measuring a perceived realistic threat and is created from the following question:

Which one of the following worries you most about Islamic identity in our country today? It can lead to a loss of personal freedoms

Respondents were assigned a value of 1 if the above option was chosen and a value of 0 if otherwise. The second variable measures perceived symbolic threat and is created as a dummy variable from the responses to a question asking:

Do you think most Muslims coming to our country today want to adopt our country's customs and way of life or do you think that they want to be distinct from the larger society?

It can be argued that respondents who think that Muslims want to be distinct (assigned a value of 1) perceive a symbolic threat to their values, because they view these people as outsiders who want to stay different from the mainstream society. The third and fourth variables measure a general perception of threat which may be regarded as realistic or symbolic. Concern about the rise of Islam is an index combining the responses from two items. These items are: "How concerned, if at all, are you about the rise of Islamic extremism around the WORLD [IN OUR COUNTRY] these days? Are you very concerned, somewhat concerned, not too concerned or not at all concerned about the rise of Islamic extremism around the WORLD [IN OUR COUNTRY] these days?” The responses were ordered from the least concerned to the most concerned and this variable takes values ranging from 2 to 8 . The fourth variable asks the respondents to evaluate the degree of hostility toward Muslims in their country and is worded as follows: 
In your opinion, how many [Americans, Germans, etc]. do you think are hostile toward Muslims - would you say most, many, just some or very few?

This variable ranges from 1 (very few) to 4 (most) and measures the degree of perceptions of societal threat according to the respondent's view. I use educational attainment to test the implications of education/cognitive abilities approach and this variable is measured with a 7-point scale across the five cases. I also include a number of control variables including a dummy variable asking the respondents whether they favor the US-led war against terror, age, income, and finally gender.

\section{Results}

Since the dependent variables are dichotomous, I use logistic regression for statistical estimation. The results for the pooled data are presented in Table 1.

Table 2: Logistic Regression Estimation Results for Islamophobic Attitudes

\begin{tabular}{|c|c|c|c|c|c|}
\hline & $\begin{array}{r}\text { Unfavorable } \\
\text { Opinion }\end{array}$ & $\begin{array}{r}\text { Islamic } \\
\text { Identity } \\
\text { Violence } \\
\end{array}$ & $\begin{array}{r}\text { Muslims } \\
\text { Violent }\end{array}$ & $\begin{array}{l}\text { Muslims } \\
\text { Fanatical }\end{array}$ & $\begin{array}{r}\text { Muslims } \\
\text { support al } \\
\text { Qaeda } \\
\end{array}$ \\
\hline \multicolumn{6}{|l|}{ Social Identity } \\
\hline National Identity & $\begin{array}{l}0.0118 \\
(0.104)\end{array}$ & $\begin{array}{r}0.386^{\star \star \star} \\
(0.139)\end{array}$ & $\begin{array}{l}0.193^{*} \\
(0.102)\end{array}$ & $\begin{array}{l}0.232^{\star \star} \\
(0.107)\end{array}$ & $\begin{array}{r}-0.105 \\
(0.113)\end{array}$ \\
\hline Christian Identity & $\begin{array}{r}-0.0754 \\
(0.134)\end{array}$ & $\begin{array}{l}0.351^{\star *} \\
(0.174)\end{array}$ & $\begin{array}{l}0.253^{\star *} \\
(0.126)\end{array}$ & $\begin{array}{r}0.145 \\
(0.134)\end{array}$ & $\begin{array}{r}0.118 \\
(0.140)\end{array}$ \\
\hline \multicolumn{6}{|l|}{$\begin{array}{l}\text { Perceived Realistic and } \\
\text { Symbolic Threat }\end{array}$} \\
\hline Perceptions of Hostility & $\begin{array}{l}0.258^{\star \star \star} \\
(0.0507)\end{array}$ & $\begin{array}{l}0.243^{\star \star \star} \\
(0.0675)\end{array}$ & $\begin{array}{l}0.352^{\star \star *} \\
(0.0496)\end{array}$ & $\begin{array}{l}0.368^{\star \star \star} \\
(0.0513)\end{array}$ & $\begin{array}{l}0.372^{\star \star \star} \\
(0.0564)\end{array}$ \\
\hline Muslims Remain Distinct & $\begin{array}{l}0.726^{\star \star *} \\
(0.0984)\end{array}$ & $\begin{array}{r}1.326^{\star * *} \\
(0.140)\end{array}$ & $\begin{array}{l}0.802^{\star * *} \\
(0.0945)\end{array}$ & $\begin{array}{l}0.986^{\star * *} \\
(0.0962)\end{array}$ & $\begin{array}{r}0.602^{* * *} \\
(0.107)\end{array}$ \\
\hline $\begin{array}{l}\text { Islamic Identity: Loss of } \\
\text { Freedom }\end{array}$ & $\begin{array}{l}0.232^{\star \star} \\
(0.108)\end{array}$ & & $\begin{array}{r}0.104 \\
(0.107)\end{array}$ & $\begin{array}{l}0.273^{\star \star} \\
(0.118)\end{array}$ & $\begin{array}{r}-0.0800 \\
(0.119)\end{array}$ \\
\hline $\begin{array}{l}\text { Concerned about Islamic } \\
\text { Extremism }\end{array}$ & $0.141^{\star \star \star}$ & $0.333^{\star \star \star}$ & $0.190^{\star \star \star}$ & $0.183^{\star \star \star}$ & $0.131^{* * *}$ \\
\hline Coqnitive Capabilities & $(0.0273)$ & $(0.0413)$ & $(0.0263)$ & $(0.0268)$ & $(0.0303)$ \\
\hline Education & $\begin{array}{l}-0.0704^{\star} \\
(0.0363)\end{array}$ & $\begin{array}{l}-0.116^{\star \star} \\
(0.0470)\end{array}$ & $\begin{array}{r}-0.144^{\star \star \star} \\
(0.0346)\end{array}$ & $\begin{array}{r}-0.191^{\star \star *} \\
(0.0367)\end{array}$ & $\begin{array}{r}-0.224^{\star \star *} \\
(0.0377)\end{array}$ \\
\hline Control Variables & & & & & \\
\hline Favor US Led War & $\begin{array}{r}0.373^{\star \star \star} \\
(0.104)\end{array}$ & $\begin{array}{l}0.339^{* *} \\
(0.136)\end{array}$ & $\begin{array}{r}0.623^{\star \star \star} \\
(0.101)\end{array}$ & $\begin{array}{r}0.597^{\star * \star} \\
(0.106)\end{array}$ & $\begin{array}{r}0.352^{\star * *} \\
(0.114)\end{array}$ \\
\hline Female & $\begin{array}{l}-0.193^{\star *} \\
(0.0923)\end{array}$ & $\begin{array}{l}0.0448 \\
(0.124)\end{array}$ & $\begin{array}{r}-0.0454 \\
(0.0894)\end{array}$ & $\begin{array}{l}-0.0456 \\
(0.0937)\end{array}$ & $\begin{array}{l}0.340 * * * \\
(0.0989)\end{array}$ \\
\hline Age & $\begin{array}{r}0.00398 \\
(0.00280)\end{array}$ & $\begin{array}{l}0.0116 * * * \\
(0.00391)\end{array}$ & $\begin{array}{r}0.00368 \\
(0.00275)\end{array}$ & $\begin{array}{l}0.0119 * * * \\
(0.00298)\end{array}$ & $\begin{aligned} 0.00553^{*} \\
(0.00304)\end{aligned}$ \\
\hline Mid-income & 0.0567 & 0.167 & -0.0296 & 0.119 & -0.126 \\
\hline
\end{tabular}




\begin{tabular}{|c|c|c|c|c|c|}
\hline High-income & $\begin{array}{r}(0.110) \\
0.190 \\
(0.139)\end{array}$ & $\begin{array}{r}(0.146) \\
0.275 \\
(0.188)\end{array}$ & $\begin{array}{r}(0.108) \\
-0.0133 \\
(0.134)\end{array}$ & $\begin{array}{l}0.114) \\
0.331^{\star *} \\
(0.142)\end{array}$ & $\begin{array}{r}(0.113) \\
-0.373^{\star \star} \\
(0.154)\end{array}$ \\
\hline Britain & $\begin{array}{r}-0.461^{\star * *} \\
(0.165)\end{array}$ & $\begin{array}{r}0.566^{\star \star \star} \\
(0.217)\end{array}$ & $\begin{array}{r}-0.896^{\star \star *} \\
(0.151)\end{array}$ & $\begin{array}{r}-0.208 \\
(0.148)\end{array}$ & $\begin{array}{l}-0.278^{\star} \\
(0.163)\end{array}$ \\
\hline France & $\begin{array}{r}0.427^{\star * *} \\
(0.142)\end{array}$ & $\begin{array}{r}2.008^{* * *} \\
(0.191)\end{array}$ & $\begin{array}{r}-0.365^{\star * *} \\
(0.138)\end{array}$ & $\begin{array}{l}0.0588 \\
(0.141)\end{array}$ & $\begin{array}{r}-0.503^{\star * *} \\
(0.160)\end{array}$ \\
\hline Germany & $\begin{array}{r}0.993^{* * *} \\
(0.140)\end{array}$ & $\begin{array}{r}1.614^{* * *} \\
(0.194)\end{array}$ & $\begin{array}{r}-0.287^{\star * *} \\
(0.141)\end{array}$ & $\begin{array}{r}0.850^{\star * *} \\
(0.151)\end{array}$ & $\begin{array}{r}-0.642^{* * *} \\
(0.165)\end{array}$ \\
\hline Spain & $\begin{array}{r}1.711^{\star * *} \\
(0.163)\end{array}$ & $\begin{array}{r}0.833^{\star * *} \\
(0.225)\end{array}$ & $\begin{array}{r}0.660^{\star * *} \\
(0.165)\end{array}$ & $\begin{array}{r}2.182^{\star * *} \\
(0.194)\end{array}$ & $\begin{array}{r}1.065^{\star * *} \\
(0.168)\end{array}$ \\
\hline Constant & $\begin{array}{r}-3.082^{\star * *} \\
(0.333)\end{array}$ & $\begin{array}{r}-6.250^{\star * *} \\
(0.503)\end{array}$ & $\begin{array}{r}-2.544^{\star * *} \\
(0.313)\end{array}$ & $\begin{array}{r}-2.986^{\star * *} \\
(0.328)\end{array}$ & $\begin{array}{r}-2.581^{\star \star \star} \\
(0.369)\end{array}$ \\
\hline $\begin{array}{l}\text { Observations } \\
\text { Count R-Squared }\end{array}$ & $\begin{array}{r}2507 \\
0.70\end{array}$ & $\begin{array}{r}1927 \\
0.80\end{array}$ & $\begin{array}{r}2507 \\
0.68\end{array}$ & $\begin{array}{r}2507 \\
0.73\end{array}$ & $\begin{array}{r}2507 \\
0.74\end{array}$ \\
\hline
\end{tabular}

Source: Pew Global Attitudes Project. The great divide: How Westerners and Muslims view each other.

Washington, DC: Pew Research Center; 2006.

Robust standard errors in parentheses

${ }^{* * *} \mathrm{p}<0.01,{ }^{* *} \mathrm{p}<0.05,{ }^{*} \mathrm{p}<0.1$

The variables included in the model explain a high amount of variation in the dependent variable. Across five estimations, the proportion of correctly predicted cases range from 68 percent in Model 3 to 80 percent in Model 2 (Count R-squared value). The determinants of Islamophobic attitudes have differential effects across various dimensions of this measure and these effects vary in size and significance. Four variables were used to measure the effects of threat perceptions. Of these variables, "Perception of Hostility to Muslims, Muslims Remain Distinct, and Concerned about Islamic Extremism” are consistently significant and in the positive direction in all five models. Thus, the results support hypotheses 3 and 4 confirming that perceived symbolic threat and the feeling of a general threat are among the strongest determinants of anti Muslim sentiment. For example, the respondents who state that they are concerned about Islamic extremism are more likely to have anti Muslim sentiments.

This effect is consistent across all indicators of Islamophobia ranging from unfavorable feeling of Muslims to the perception of Muslims as supportive of al Qaeda. However, a second indicator of perceived realistic threat, "Islamic identity may lead to a loss of freedom", does not reach statistical significance in all models, and this variable is dropped in Model 2 due to collinearity (strong correlation between variables). On the other hand, all indicators of perceived symbolic threat on attitudes toward Muslims appear to be positive and consistently significant across five models. Individuals who believe that Muslims remain distinct from the mainstream society are more likely to have unfavorable attitudes toward Muslims and associate them with violence, fanaticism, or terrorism. A positive and statistically significant effect is also observed for the variable measuring the perception of degree of hostility toward Muslims in the respondent's country. Overall, these results are in line with the findings of past studies linking symbolic threat to anti Muslim sentiments. ${ }^{42}$ 
Indicators of social identity fail to reach statistical significance in all models. National attachment is more consistently related to anti Muslim sentiment compared to the effect of scarcely significant religious attachment. This finding is at odds with the results of past studies detecting an association between Christian religiosity and anti Muslim sentiments. ${ }^{43}$ Given the significance of religion and high rates of church attendance in the United States compared to Europe, the results in Table 1 may be reflective of an average impact in the West. Religious identity may have context bound effects and I investigate the differences across five nations with the country level estimations below.

The single indicator measuring cognitive abilities, education, reduces negative feelings about Muslims consistently in all models. An individual with higher levels of education is less likely to have an unfavorable opinion of Muslims or less likely to view Muslims as fanatical, violent, or supportive of terrorism. Thus, the results confirm hypotheses 5. Of control variables income has no statistically significant effect and the impact of gender is inconsistent. Finally, anti Muslim attitudes get stronger with age.

To elaborate further, I calculated the predicted probabilities for indicators of perceived threat and I report these for selected variables in Models 1, 3 and 5. In calculating these figures, the variables of interest were increased from minimum to maximum (a change from 0 to 1 for dummy variables) while all others were set to their mean. Figure 2 reports the change in probabilities based on the min-max increase for three models. To reiterate, the dependent variable is "Favorable Opinion of Muslims" in Model 1, "Muslims are Violent" in Model 2, and "Muslims Support Al Qaeda" in Model 5.

Figure 2: Change in Predicted Probabilities of Perceived Threat Variables on Islamophobic Attitudes

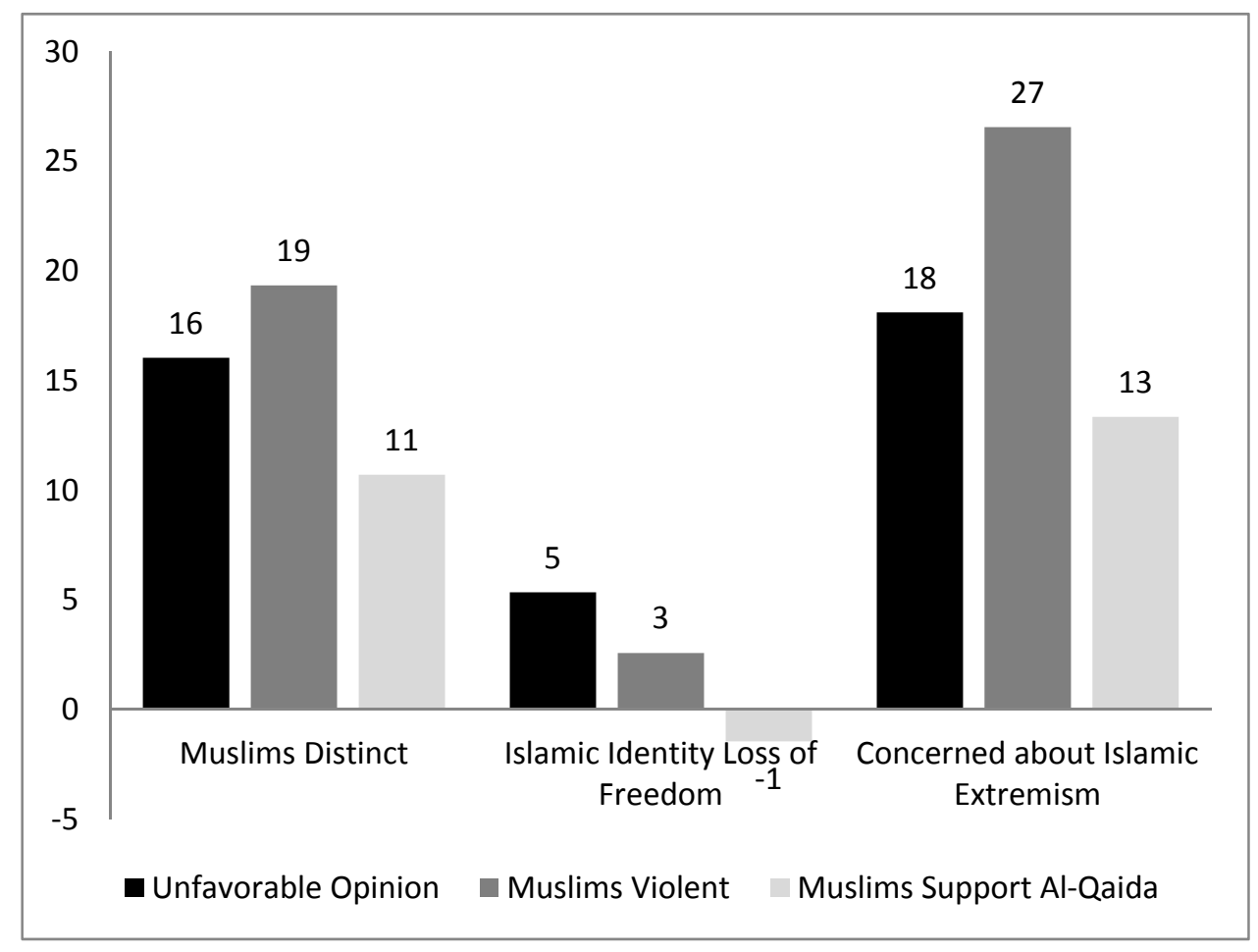


Source: Pew Global Attitudes Project. The great divide: How Westerners and Muslims view each other. Washington, DC: Pew Research Center; 2006.

Figure 2 reports the change in predicted probabilities for indicators of perceived symbolic threat (Muslims Distinct), realistic threat (Islamic Identity leads to Loss of Freedom), and a variable measuring perception of both symbolic and realistic threat (Concerned about the Rise of Islamic Extremism) across selected models. The variable measuring the overall threat has the largest substantive impact on the three measures of Islamophobic attitudes. An individual who is concerned with the rise of Islamic extremism is 18 percent more likely to have an unfavorable view of Muslims relative to an individual who does not have such a fear. The same individual is 27 percent more likely to believe that Muslims are violent and 13 percent more likely to associate Muslims with al Qaeda compared to a person who is not concerned with the rise of Islamic extremism. The change in probabilities for the effect of the perceived symbolic threat (Muslims Distinct) on anti Muslim sentiment also remains substantively high. For example, an individual who believes that Muslims remain distinct and do not integrate into the mainstream society is 16 percent more likely to hold an unfavorable view of Muslims compared to an individual with the opposite perception. The same figure is 19 percent for the perception of Muslims as violent and 11 percent for the views about Muslims' support for al Qaeda. The middle section of Figure 2 shows that the fear that Islamic identity may lead to a loss of freedom (i.e. Realistic threat) has a substantively smaller effect on anti Muslim sentiment of any kind.

The results from the pooled models show average effect of individual determinants of anti Muslim sentiment in five Western countries. Important differences exist between these countries in terms of their Muslim population and the mood of public. While the country effects in the models control for the cross-national variation, they do not show which indicators are more significant across these countries. Thus, I ran country specific logistic regressions and Table 3 reports the estimation results from these models. The table presents the odds ratios which represent the chances of observing support against non-support for each dependent variable given the change in independent variables.

Table 3 Here

I focus on the results for "Muslims Violent" and "Muslims Support al Qaeda" equations which will allow me compare the determinants of a view about Muslims' tendency to violence and another view that perceives the Muslims at the most extreme position. Full results are available from the author upon request.

Generally, the results at the country level confirm the findings in the pooled models. Two indicators of perceived threat theory (Muslims Remain Distinct and Perceptions of Hostility to Muslims) reach the levels of statistical significance in all five countries. For example, a British citizen who perceives Muslims to be distinct from the mainstream society is 2.6 times more likely to view Muslims as violent. The odds are 2.8 times larger for a French citizen while the same odds are 2.1 for German, 1.7 for Spanish, and 2.1 times more for American citizens. A 
similar impact predicts negative sentiments when Western citizens are concerned about the rise of Islamic extremism. However, threat perceptions have limited explanatory power about perceptions of Muslims as terrorism supporters. While select indicators of threat perceptions lead individuals to view Muslims as supportive of al Qaeda, this association is observed only in France, Germany and Spain. Finally, as detected in the pooled models, cognitive capabilities approach finds support in both models. As the level of education increases, individuals become less likely to hold negative attitudes about Muslims.

National and religious attachments appear to have limited explanatory power in predicting the likelihood of negative sentiments among the Western citizens. In the US, strong national and religious identity increases the likelihood of viewing Muslims as violent. The odds that an individual with strong Christian identity will hold such attitudes are 1.68 times larger than for someone who has week religious identity. This result is in line with the findings of past studies $^{44}$ establishing an association between religiosity and lack of tolerance in the United States. Conversely this impact is non-existent in Europe. Only German citizens holding a strong Christian identity are less likely to believe that Muslims support al Qaeda. Apparently, high levels of church attendance and religiosity in the United States differentiate respondents from those in Europe where religion has a less significant role. ${ }^{45}$

\section{Discussion}

The rise of Islamophobia in the West has raised concerns among scholars and policymakers. While the mainstream media and some political leaders associate Islam with violence, the reports by prominent organizations focus upon a general dislike of Muslims. In this paper, I examined the individual sources of both types of Islamophobic attitudes and I tested the implications of three prominent theories developed by the students of ethnic/religious tolerance and race: Social identity, perceived symbolic and realistic threat, and cognitive capabilities.

An initial look at the descriptive figures revealed that Western citizens hold multiple forms of Islamophobic attitudes and these attitudes range from a general feeling about Muslims to the perception of Muslims as supportive of terrorist organizations. In addition, citizens' orientations widely differ across five Western nations. Muslims are viewed most unfavorably in Spain and Germany. When asked about Muslim support for al Qaeda, 68 percent of citizens in Spain and 54 percent in the United States hold affirmative views. Spain is used as a gateway by West and North African Muslim refugees and the tide of illegal immigrants has been on the rise since its accession to the European Union. The increasing number of North African Muslims may have increased the anti Muslim feelings among Spaniards. On the other hand, the impact of 9/11 and the political capitalization of "War on Terror" may partially account for the perceptions of Muslims as terrorists among Americans. In contrast, public opinion in Germany, France, and Britian appears to be less accepting of the view that Muslims are supportive of terrorism. More interestingly, while less than a third of respondents in five countries believe that Islamic identity leads to violence, the proportion of those that view Muslims as violent or fanatical is over or 
around 50 percent (one exception is Britain where public opinion appears to be the least Islamophobic). This discrepancy may be reflective of the fact that Western citizens distinguish between Islam as an abstract concept and Muslims as real human beings. According to the data in hand, attitudes toward the general concept of Islam obtain a less negative tone in contrast to the perception of Muslims.

The empirical analysis carried here also sought to explain the cognitive sources of Islamophobic attitudes. The results do not support social identity theory as the effect of national and Christian identity is not statistically significant in most models. However, when analysis is replicated at the country level, attachment to religious identity becomes a possible source of negative sentiments toward Muslims in the United States. This American exceptionalism may be due to the prominent role of religion as exemplified by high church attendance rates relative to those found in the European polities. The results of the analysis confirm cognitive capabilities theory and more educated people are found to be less Islamophobic in the West.

Finally, the results of the empirical analysis most strongly support the implications of perceived threat theories. In all models, individuals are found to be more likely to hold anti Muslim attitudes if they feel that their culture or well-being is threatened by Muslims. For example, an individual is more likely to have an unfavorable opinion about Muslims or believe that Muslims are violent if s/he thinks that Muslims remain distinct from the mainstream society (symbolic threat) or if s/he is concerned about the rise of Islamic extremism (general threat). Although this effect varies across various types of Islamophobic attitudes, the link between perceived symbolic threat and anti Muslim sentiment remains strong.

\section{Conclusion}

Islamophobia has reached unprecedented levels in the West. The analysis in this paper showed that fear of Muslims and perceived threat accounts for much of the variation in the realm of attitudes. Western citizens view Muslims as fanatical, violent and supportive of terrorism because they perceive them to be threatening to their physical well-being and cultural values. This feeling is exploited by media and right-wing leaders to feed the xenophobia of a new kind. More needs to be done to change this misperception. One policy solution is to increase knowledge of Islam explained correctly. An informed citizenry may be less inclined to perceive a threat from all Muslims and hence may be the cure to for the unfounded hostility and fear of Islam in the West.

\section{NOTES}

${ }^{1}$ EUMC, Anti Islamic Reactions within the European Union after the Acts of Terror Against the USA. Country Report of the Netherlands Covering the Period 12th September-31st December 2001, Vienna: EUMC, 2002; EUMC, The Fight Against Anti Semitism and Islamophobia. 
Bringing Communities Together, Brussels and Vienna: EUMC, 2003; EUMC, Racism and Xenophobia in the EU Member States Trends, Developments And Good Practice, Brussels and Vienna: EUMC, 2004; EUMC, Muslims in the European Union: Discrimination And Islamophobia, Vienna: EUMC, 2006.

${ }^{2}$ CAIR, The Status of Muslim Civil Rights in the United States, Washington, DC: CAIR, 2006.

3 John Esposito and Dalia Mogahed, "Battle for Muslims' Hearts and Minds: The Road Not (Yet) Taken”, Middle East Policy, Vol. 14, No. 1, 2007, pp. 27-41.

4 James Gibbon, “Unveiling Islamophobia: American Attitudes Toward Islam,” December, 2005, accessed December 15, 2009accessed at http://jimgibbon.com/wpcontent/uploads/2006/05/Gibbon-UnveilingIslamophobia.pdf; Kerem Ozan Kalkan, Geoffrey. Layman, and Eric Uslaner, "Bands of Others? Attitudes toward Muslims in Contemporary American Society”, Journal of Politics, Vol. 71, No. 3, 2009, pp. 1-16; C. E. Smidt, "Religion and American Attitudes Toward Islam and Invasion of Iraq", Sociology of Religion, Vol. 66, No. 1, 2005, pp. 243-261; Z. Strabac and O. Listhaug, “Anti Muslim Prejudice in Europe: A

Multilevel Analysis of Survey Data From 30 Countries”, Social Science Research, Vol. 37, No. 1, 2008, pp. 268-286; for an exception see Richard Wike and Brian J. Grim, “Western Views Toward Muslims: Evidence from a 2006 Cross-National Survey”, International Journal of Public Opinion Research, Vol. 22 No. 1 2010, pp. 4-25.

${ }^{5}$ Fernando Bravo López, “Towards a Definition of Islamophobia: Approximations of the Early Twentieth Century”, Ethnic and Racial Studies, Vol. 34 No. 4, 2011, pp. 556-573, at 556.

${ }^{6}$ Jocelyne Cesari, "Islamophobia in the West: A Comparison between Europe and America" in Islamophobia: The Challenge of Pluralism in the 21st Century, edited by John L. Esposito and Ibrahim Kalin, New York: Oxford University Press, 2011, p. 21-23.

${ }^{7}$ Sabine Schiffer and Constantine Wagner, “Anti-Semitism and Islamophobia-New Enemies, Old Patterns”, Race and Class, Vol. 52, No. 1, 2011, pp. 77-84, at 79.

8 Ibrahim Kalin, "Islamophobia and the Limits of Multiculturalism", in Esposito and Kalin, Islamophobia The Challenge of Pluralism in the 21st Century, op. cit.

${ }^{9}$ H. Dekker and J. Van Der Noll, "Islamophobia and Its Origins. A Study Among Dutch Youth”, September 6, 2007, accessed January 10, 2012, http://www.uu.nl/SiteCollectionDocuments/SW/ Ercomer/digital\%20 publications/dekker_pisa07.pdf.

${ }^{10}$ J. Zimmermann, “A Review of: "Hillel Schenker and Ziad Abu-Zayyad. Islamophobia and Anti-Semitism”, Terrorism and Political Violence, Vol. 20, No. 3, 2008, pp. 454-456, at 454.

${ }^{11}$ A.S. Roald, New Muslims in the European Context: The Experience of Scandinavian Converts, 
amophobia and European Identity", in The Fight Against Anti Semitism inging Communities Together, EUMC, Brussels: European Monitoring Xenophobia, 2003, pp. 61-64; Goran Larsson, "The Impact of Global atexts: Muslims in Sweden after 9/11-The Rise of Islamophobia, or New nd Christian-Muslim Relations, Vol. 16, No. 4. 2005, pp. 29-42.

am in German Media”, in Islam and Muslims in Germany, edited by Ala Thielmann, Leiden, Boston: Brill, 2007, pp. 423-440.

ring Islam: How the Media and the Experts Determine How We See the don: Vintage, 1997; Elizabeth Poole, Reporting Islam: Media tish Muslims, London: I.B.Tauris, 2002.

incent Price, and Hayg Oshagan, "Press Treatment of Islam: What Kind of Paint?” International Communication Gazette, Vol. 56, No. 2, 1996, pp.

oduction,” in Esposito and Kalin, Islamophobia The Challenge of Century, op. cit.; Brigitte L. Nacos and Oscar Torres-Reyna "Muslim s Before and After 9-11", (paper Presented at the Symposium "Restless , The Media \& Public Life, John F. Kennedy School, Harvard University

Islamophobia: American Attitudes Toward Islam”, op. cit.; Smidt, an Attitudes Toward Islam and Invasion of Iraq”, op. cit.; Kalkan, Layman, Others”, op. cit.; John Sides and Jack Citrin, “European Opinion About of Identities, Interests and Information”, British Journal of Political 3, 2007, pp. 477-504; John Sides and Kimberly Gross, Stereotypes of the for the War on Terror, January, 2011, accessed January 5, 2011, jsides/muslims.pdf; Strabac and Listhaug, “Anti Muslim Prejudice in and Grim, "Western Views Toward Muslims”, op. cit.

C. Turner, "An Integrative Theory of Intergroup Conflict”, in The Social

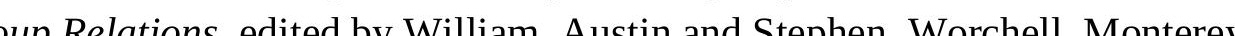


${ }^{27}$ W.G. Stephan, Y. Oscar, and B. Guy, “A Threat Model of Prejudice: The Case of Immigrants”, Journal of Applied Social Psychology, Vol. 29, No. 11, 1999, pp. 2221-37.

${ }^{28}$ Lauren M. McLaren, “Anti Immigrant Prejudice in Europe: Contact, Threat Perception, and Preferences for the Exclusion of Migrants”, Social Forces, Vol. 81, No. 3, 2003, pp. 909-936; P.Scheepers, M. Gijsberts, and M. Coenders, "Ethnic Exclusionism in European Countries.

Public Opposition to Civil Rights for Legal Migrants as Response to Perceived Ethnic Threat”, European Sociological Review, Vol. 18, No. 1, 2002, pp. 17-34.

${ }^{29}$ Muzafer Sherif, In Common Predicament: Social Psychology of Intergroup Conflict and Cooperation, Boston: Houghtin Mifflin, 1966.

${ }^{30}$ Jocelyn Cesari, When Islam and Democracy Meet: Muslims in Europe and the United States, New York: Palgrave Macmillan, 2004.

${ }^{31}$ Robert Leiken, “Europe’s Angry Muslims”, Foreign Affairs, Vol. 84, July-August 2005, pp. 120-35.

32 David O Sears, "Symbolic Racism”, in Eliminating Racism: Profiles in Controversy, edited by P.A. Katz and D.A. Taylor, New York: Plenum Press, 1988, pp. 53-84.

${ }^{33}$ Donald R. Kinder, and David O. Sears, "Prejudice and Politics: Symbolic Racism versus Racial Threats to the Good Life", Journal of Personality and Social Psychology, Vol. 40, No. 3, 1981, pp. 414-31; P.M. Sniderman, L. Hagendoorn, and M. Prior, "Predisposing Factors and Situational Triggers: Exclusionary Reactions to Immigrant Minorities”, American Political Science Review, Vol. 98, No. 1, 2004, pp. 35-49; Citrin and Sides, "European Opinion About Immigration”, op. cit.; Wike and Grim, "Western Views Toward Muslims op. cit.

${ }^{34}$ K. M. Moore, Al Mughtaribun: American Law and the Transformation of Muslim Life in the United States, Albany, NY: State University Of New York Press, 1995.

${ }^{35}$ Geert Wilders, Online Speech, May 12, 2011, accessed January 5, 2012, on http://islamophobiatv.wordpress.com /2011/06/01/dutch-politician-geert-wilders-speaks-aboutislam-at-u-s-megachurch.

${ }^{36}$ Cesari, When Islam and Democracy Meet, op. cit.; : Cesari, "Islamophobia in the West", op. cit.

${ }^{37}$ W. P Vogt, Tolerance \& Education: Learning to Live with Diversity and Difference, London: Sage Publications, 1997.

${ }^{38}$ G. J. Selznick and S. Stephen, The Tenacity of Prejudice: Anti Semitism in Contemporary America, New York: Harper And Row,1969.

${ }^{39}$ M. Coenders and P. Scheepers, "The Effect of Education on Nationalism and Ethnic 
e Role of Threats in the Racial Attitudes of Blacks and Whites", op. cit;

rn, and Prior, "Predisposing Factors and Situational Triggers", op. cit; tern Views toward Muslims”, op. cit.

stman, and J. Shanahan, "Public Opinion toward Muslim Americans: Civil of Religiosity, Ideology, and Media Use,” in Muslims in Western Politics, Bloomington: Indiana University Press, 2009.

Evangelicals and Political Tolerance”, op. cit; Wald, Religion and Politics p. cit.

nglehart, Sacred and Secular: Religion and Politics Worldwide, New Press, 2005. 
TABLE 3

Individual Sources of Islamophobic Attitudes across Five Western Nations

\begin{tabular}{|c|c|c|c|c|c|c|c|c|c|c|}
\hline & \multicolumn{2}{|c|}{ Britain } & \multicolumn{2}{|c|}{ France } & \multicolumn{2}{|c|}{ Germany } & \multicolumn{2}{|c|}{ Spain } & \multicolumn{2}{|c|}{ United States } \\
\hline & $\begin{array}{r}\text { Muslims } \\
\text { Violent }\end{array}$ & $\begin{array}{r}\text { Muslims } \\
\text { Support } \\
\text { al Qaeda }\end{array}$ & $\begin{array}{r}\text { Muslims } \\
\text { Violent }\end{array}$ & $\begin{array}{r}\text { Muslims } \\
\text { Support } \\
\text { al Qaeda }\end{array}$ & $\begin{array}{r}\text { Muslims } \\
\text { Violent }\end{array}$ & $\begin{array}{r}\text { Muslims } \\
\text { Support } \\
\text { al Qaeda }\end{array}$ & $\begin{array}{r}\text { Muslims } \\
\text { Violent }\end{array}$ & $\begin{array}{r}\text { Muslims } \\
\text { Support } \\
\text { al Qaeda }\end{array}$ & $\begin{array}{l}\text { Muslims } \\
\text { Violent }\end{array}$ & $\begin{array}{l}\text { Muslims } \\
\text { Support } \\
\text { al Qaeda }\end{array}$ \\
\hline National Identity & $\begin{array}{r}1.398 \\
(0.394)\end{array}$ & $\begin{array}{r}0.743 \\
(0.242)\end{array}$ & $\begin{array}{r}1.153 \\
(0.270)\end{array}$ & $\begin{array}{r}3.309 * * * \\
(1.440)\end{array}$ & $\begin{array}{r}0.895 \\
(0.224)\end{array}$ & $\begin{array}{r}1.154 \\
(0.349)\end{array}$ & $\begin{array}{r}1.073 \\
(0.255)\end{array}$ & $\begin{array}{l}0.567^{\star \star} \\
(0.133)\end{array}$ & $\begin{array}{r}1.688^{\star \star *} \\
(0.335)\end{array}$ & $\begin{array}{r}1.023 \\
(0.224)\end{array}$ \\
\hline Christian Identity & $\begin{array}{r}1.314 \\
(0.534)\end{array}$ & $\begin{array}{r}1.888 \\
(0.805)\end{array}$ & $\begin{array}{r}1.683 \\
(0.676)\end{array}$ & $\begin{array}{r}1.154 \\
(0.151)\end{array}$ & $\begin{array}{r}0.717 \\
(0.209)\end{array}$ & $\begin{array}{l}0.432^{\star \star} \\
(0.180)\end{array}$ & $\begin{array}{r}1.010 \\
(0.388)\end{array}$ & $\begin{array}{r}0.984 \\
(0.372)\end{array}$ & $\begin{array}{r}1.767^{\star \star \star} \\
(0.360)\end{array}$ & $\begin{array}{r}1.218 \\
(0.270)\end{array}$ \\
\hline Perception of Hostility & $\begin{array}{r}1.521^{\star \star \star} \\
(0.205)\end{array}$ & $\begin{array}{r}1.994^{\star \star \star} \\
(0.295)\end{array}$ & $\begin{array}{r}1.210^{\star} \\
(0.134)\end{array}$ & $\begin{array}{r}2.095^{\star \star \star} \\
(0.578)\end{array}$ & $\begin{array}{r}1.675^{\star \star \star} \\
(0.235)\end{array}$ & $\begin{array}{r}1.800 * * \star \\
(0.319)\end{array}$ & $\begin{array}{r}1.483^{\star \star \star} \\
(0.169)\end{array}$ & $\begin{array}{r}1.366 * \star \star \\
(0.153)\end{array}$ & $\begin{array}{r}1.437^{\star \star \star} \\
(0.121)\end{array}$ & $\begin{array}{r}1.337^{\star \star \star} \\
(0.120)\end{array}$ \\
\hline Muslims Remain Distinct & $\begin{array}{r}2.608^{\star \star \star} \\
(0.756)\end{array}$ & $\begin{array}{r}1.450 \\
(0.441)\end{array}$ & $\begin{array}{r}2.820 * * * \\
(0.615)\end{array}$ & $\begin{array}{r}0.956 \\
(0.262)\end{array}$ & $\begin{array}{r}2.145^{\star \star \star} \\
(0.598)\end{array}$ & $\begin{array}{r}2.187^{*} \\
(0.933)\end{array}$ & $\begin{array}{l}1.672^{\star \star} \\
(0.390)\end{array}$ & $\begin{array}{r}1.349 \\
(0.314)\end{array}$ & $\begin{array}{r}2.134^{* * *} \\
(0.334)\end{array}$ & $\begin{array}{r}2.073^{\star * *} \\
(0.358)\end{array}$ \\
\hline $\begin{array}{l}\text { Islamic Identity: Loss of } \\
\text { Freedom }\end{array}$ & 1.246 & 0.985 & 0.749 & $1.383^{\star \star *}$ & 0.890 & 0.807 & 1.527 & 0.996 & $1.683^{\star *}$ & 1.133 \\
\hline $\begin{array}{l}\text { Concerned about Islamic } \\
\text { Extremism }\end{array}$ & $\begin{array}{r}(0.351) \\
1.267^{\star \star \star}\end{array}$ & $\begin{array}{r}(0.313) \\
1.071\end{array}$ & $\begin{array}{r}(0.171) \\
1.298^{\star \star \star}\end{array}$ & $\begin{array}{r}(0.118) \\
1.383^{\star \star \star}\end{array}$ & $\begin{array}{r}(0.206) \\
1.332^{\star \star \star}\end{array}$ & $\begin{array}{r}(0.238) \\
1.413^{\star \star \star}\end{array}$ & $\begin{array}{r}(0.441) \\
1.069\end{array}$ & $\begin{array}{l}(0.271) \\
1.120 \star \star\end{array}$ & $\begin{array}{r}(0.410) \\
1.222^{\star \star \star}\end{array}$ & $\begin{array}{r}(0.281) \\
1.066\end{array}$ \\
\hline & $(0.101)$ & $(0.0902)$ & $(0.0856)$ & $(0.118)$ & $(0.0934)$ & $(0.140)$ & $(0.0593)$ & $(0.0612)$ & $(0.0543)$ & $(0.0524)$ \\
\hline Favor US Led War & $\begin{array}{l}1.884^{\star \star} \\
(0.473)\end{array}$ & $\begin{array}{r}1.682^{\star} \\
(0.467)\end{array}$ & $\begin{array}{r}2.304^{\star \star \star} \\
(0.498)\end{array}$ & $\begin{array}{r}1.561^{\star} \\
(0.403)\end{array}$ & $\begin{array}{r}1.934^{\star \star \star} \\
(0.447)\end{array}$ & $\begin{array}{r}1.631^{*} \\
(0.469)\end{array}$ & $\begin{array}{r}1.305 \\
(0.388)\end{array}$ & $\begin{array}{r}1.756^{\star} \\
(0.509)\end{array}$ & $\begin{array}{l}1.465^{\star \star} \\
(0.280)\end{array}$ & $\begin{array}{r}0.812 \\
(0.165)\end{array}$ \\
\hline Female & $\begin{array}{r}0.952 \\
(0.237)\end{array}$ & $\begin{array}{r}1.162 \\
(0.318)\end{array}$ & $\begin{array}{r}0.952 \\
(0.205)\end{array}$ & $\begin{array}{l}1.954^{\star *} \\
(0.511)\end{array}$ & $\begin{array}{r}1.178 \\
(0.266)\end{array}$ & $\begin{array}{r}1.395 \\
(0.402)\end{array}$ & $\begin{array}{r}0.875 \\
(0.189)\end{array}$ & $\begin{array}{r}1.203 \\
(0.255)\end{array}$ & $\begin{array}{r}0.805 \\
(0.127)\end{array}$ & $\begin{array}{r}1.377^{*} \\
(0.236)\end{array}$ \\
\hline Age & $\begin{array}{r}0.996 \\
(0.00814)\end{array}$ & $\begin{array}{r}0.992 \\
(0.00879)\end{array}$ & $\begin{array}{r}1.009 \\
(0.00656)\end{array}$ & $\begin{array}{r}1.004 \\
(0.00756)\end{array}$ & $\begin{array}{r}0.998 \\
(0.00688)\end{array}$ & $\begin{array}{r}1.026^{\star * \star} \\
(0.00905)\end{array}$ & $\begin{array}{r}0.984^{\star \star} \\
(0.00742)\end{array}$ & $\begin{array}{r}0.998 \\
(0.00729)\end{array}$ & $\begin{array}{r}1.013^{\star \star \star} \\
(0.00486)\end{array}$ & $\begin{array}{r}1.006 \\
(0.00515)\end{array}$ \\
\hline Income & $\begin{array}{r}0.913 \\
(0.0841)\end{array}$ & $\begin{array}{r}0.808^{\star *} \\
(0.0843)\end{array}$ & $\begin{array}{r}0.877^{*} \\
(0.0646)\end{array}$ & $\begin{array}{r}0.789 \star * \\
(0.0728)\end{array}$ & $\begin{array}{r}1.069 \\
(0.0576)\end{array}$ & $\begin{array}{r}0.967 \\
(0.0681)\end{array}$ & $\begin{array}{r}1.028 \\
(0.0847)\end{array}$ & $\begin{array}{r}1.010 \\
(0.0812)\end{array}$ & $\begin{array}{r}1.036 \\
(0.0396)\end{array}$ & $\begin{array}{r}0.984 \\
(0.0406)\end{array}$ \\
\hline Education & $\begin{array}{r}0.829^{*} \\
(0.0814)\end{array}$ & $\begin{array}{l}0.650 * \star \star \\
(0.0714)\end{array}$ & $\begin{array}{r}0.851^{*} \\
(0.0749)\end{array}$ & $\begin{array}{r}0.815^{\star} \\
(0.0899)\end{array}$ & $\begin{array}{r}0.828^{\star *} \\
(0.0795)\end{array}$ & $\begin{array}{r}0.934 \\
(0.118)\end{array}$ & $\begin{array}{l}0.825^{\star \star \star} \\
(0.0610)\end{array}$ & $\begin{array}{r}0.840 * \star \\
(0.0611)\end{array}$ & $\begin{array}{r}0.940 \\
(0.0526)\end{array}$ & $\begin{array}{l}0.806^{\star \star *} \\
(0.0488)\end{array}$ \\
\hline Constant & $\begin{array}{r}0.0354^{\star \star *} \\
(0.0298)\end{array}$ & $\begin{array}{r}0.270 \\
(0.238)\end{array}$ & $\begin{array}{r}0.0627^{* \star *} \\
(0.0428)\end{array}$ & $\begin{array}{r}0.0208^{\star * *} \\
(0.0179)\end{array}$ & $\begin{array}{r}0.0288^{\star \star *} \\
(0.0226)\end{array}$ & $\begin{array}{l}0.0008^{\star \star *} \\
(0.00102)\end{array}$ & $\begin{array}{r}1.055 \\
(0.768)\end{array}$ & $\begin{array}{r}0.458 \\
(0.330)\end{array}$ & $\begin{array}{r}0.0256 * \star \star \\
(0.0136)\end{array}$ & $\begin{array}{l}0.169 * * * \\
(0.0925)\end{array}$ \\
\hline Observations & 385 & 385 & 486 & 486 & 435 & 435 & 398 & 398 & 805 & 805 \\
\hline
\end{tabular}

Source: Pew Global Attitudes Project. The great divide: How Westerners and Muslims view each other. Washington, DC: Pew Research Center; 2006.

The numbers are odds ratios. Standard Errors are in parentheses $\backslash$

$* * * \mathrm{p}<0.01, * * \mathrm{p}<0.05, * \mathrm{p}<0.1$ 
